British Journal of Educational Studies Vol. 62, No. 3, September 2014, pp. 337-354

\title{
PLACING 'KNOWLEDGE' IN TEACHER EDUCATION IN THE ENGLISH FURTHER EDUCATION SECTOR: AN ALTERNATIVE APPROACH BASED ON COLLABORATION AND EVIDENCE-BASED RESEARCH
}

\author{
by SAI Y. LOO, Institute of Education, University of London
}

\begin{abstract}
This paper focuses on teacher education in the English further education sector, where the teaching of disciplinary and pedagogic knowledge is an issue. Using research findings, the paper advocates an approach based on collaboration and informed research to emphasize and integrate knowledge(s) in situated teaching contexts despite working in a climate of competition as advocated by the current neo-liberal government.
\end{abstract}

Keywords: teacher education, teaching knowledge, collaboration, informed research

\section{INTRODUCTION}

This article considers the implications of some of the current international debates on teacher education, and in particular the further education (FE) sector, in England with the revised publications of Teaching and Training Qualifications for the Further Education and Skills Sector in England (Learning and Skills Improvement Service [LSIS], 2013a, 2013b) and Professional Standards for Teachers and Trainers in England (Pye Tait Consulting, 2014). These perspectives involve two trends in particular (Tatto, 2013). The first relates to the growing importance of teaching knowledge in teacher training in order that teachers can apply this knowledge to their teaching so their learners acquire disciplinary knowledge and apply it critically and creatively. The second trend relates to teaching, which is perceived as 'knowledge and context-situated ... that combine a complex set of features such as disciplinary knowledge, theories of teaching and learning, and practical knowledge ...' (Tatto, 2013, p. 17).

These two trends have direct implications for FE teacher training in England not only because of the recent revisions to the teaching and training qualifications (LSIS, 2013a, 2013b) and professional standards (Pye Tate Consulting, 2014), although the focus is on the curriculum of teacher education and not teachers' professionalism, but also because of the numerous reports that focused on teaching in general, such as The Importance of Teaching (Department for Education [DfE], 2010), and teaching of vocational education and training in particular, such as the Wolf Report (DfE, 2011), the Richard Review of Apprenticeships (Department for Business, Innovation and Skills [BIS], 
| $t$

$\Rightarrow$ d R g a

338 PLACING KNOWLEDGE IN ENGLISH FE TEACHER EDUCATION

2012a), the Lingfield Report (BIS, 2012b) and the Commission on Adult Vocational Teaching and Learning (LSIS, 2013c).

The current Coalition government views quality teaching as central to pedagogic practices in all education sectors in England (DfE, 2010) even though it is no longer mandatory for FE teachers to acquire a teaching qualification (BIS, 2012b), which may have significant implications for in-service courses. Teaching institutions in the FE sector may be tempted to use the 30 hours of continuous professional development per annum rule (BIS, 2012b) to offer teachers without teaching qualifications 'top-up' pedagogic activities. These top-up activities may appear to support the essence of the White Paper The Importance of Teaching (DfE, 2010), which emphasized the importance of a practical and craft-like approach to teaching. However, the quality of this provision might be questioned. Similarly, the traditional role of higher education institutions (HEIs) offering teacher education (e.g. in-service courses) in the sector is also open to debate, in part due to the HEIs' ad hoc and insufficient emphasis on the research base and theorization of pedagogic practices in relation to the sector. If FE teachers are professionalized through a practical and craft-like approach without the integration of theoretical frameworks, the result would be an inferior professionalism. The assertion of this article is that the under-researched and under-theorized field of FE teacher education should be reversed. There needs to be much greater collaboration between FE institutions, HEIs and relevant stakeholders with an emphasis on knowledge, both disciplinary and pedagogic, at the heart of teacher education. This collaborative and evidence-based approach would redefine the teacher education landscape in the sector where meaningful partnerships could be formed.

The link emphasized by the neo-Liberal Coalition government (and to an extent also the previous New Labour government) on education and training with economic competitiveness has been supported by international assessments such as Trends in International Mathematics and Science Study, Progress in International Reading Literacy Study and the Program for International Student Assessment (Tatto, 2013). Neo-Liberal policies seek to create appropriate market conditions in order to reform the country's perceived over-bureaucratic, inefficient and unproductive public sector. However, competition in unfettered market conditions is not as productive as collaborative practices where stakeholders come together with a common vision to achieve an outcome (Hefferman, 2014; Sawyer, 2007).

The data for this article are based on teachers who have worked in the FE sector and have occupational experience. FE comprises the following teaching 
environments: FE colleges, voluntary and community-sector organizations, commercial organizations and independent training providers, adult and community learning providers, industry, specialist colleges, armed and uniformed services, prisons and offender learning institutions, and other public-sector organizations (Education and Training Foundation, 2014).

The delivery of occupational/vocational training programmes characterizes this sector. The pre-requisites for teachers who teach on these programmes are to apply their disciplinary/occupational knowledge to their pedagogic activities. In

\section{PLACING KNOWLEDGE IN ENGLISH FE TEACHER EDUCATION 339}

this way, FE teachers with occupational experience are able to inform their professional knowledge on an ongoing basis. This occupational experience of FE teachers distinguishes them from the other teachers in the compulsory education sectors of primary and secondary education (BIS, 2012b, 2014; DfE, 2011; LSIS, 2013c).

It is within these contexts that this article argues for the placing of disciplinary and pedagogic knowledge, at present under-developed and inconsistent, in the training of teachers in the FE sector in England. This article provides an approach to integrating disciplinary and pedagogic knowledge from a combination of collaboration with relevant stakeholders and engagement by teachers, researchers and policy-makers with research activities.

\section{THEORETICAL FRAMEWORKS}

The purpose of this article is to re-examine teacher training in the FE sector, and thus its related curriculum is imperative in this investigation. For Young (2013, pp. 101-102), 'the purpose of the curriculum, at least in modern societies, is not only to transmit past knowledge; it is to enable the next generation to build on that knowledge and create new knowledge'. The statement encapsulates the premise of this article from the perspective of teacher education in a sector where pedagogic and disciplinary/occupational-related knowledge are uniquely combined with life experiences. Education, and especially FE, viewed as a backwater within the social science disciplines, has drawn on knowledge from other disciplines such as psychology, sociology and business and management. There is room for more evidence-based research findings (as shown by the current under-developed and inconsistent practices of FE teacher education), which reinforces the position that FE-related pedagogic knowledge is missing from government reports and teaching qualification specifications (Further Education National Training Organisation, 1999; LSIS, 2013a). Not surprisingly, there has been scant attempt to even define knowledge in the previously mentioned documents. Two decades ago, Coffield (1998) remarked on this serious omission of addressing the teaching and learning 
processes in policy documents with an implicit notion that these processes and related teaching knowledge were somehow commonly known and agreed by the relevant community. It is with this backdrop from the perspectives of FE teacher education that this article proceeds.

For teacher training in the sector, 'knowledge' is complicated by the fact that trainee teachers require teaching knowledge that is associated with the learning contexts such as learners, environment, teaching organizations, group size, programmes and levels. In addition, trainee teachers are likely to have disciplinary knowledge that they have acquired through formal education such as an undergraduate course and related occupational experiences. These combinations of disciplinary, occupation-related experiences, pedagogic and life experiences form the complex interaction of 'knowledges' in FE teacher training and how

\section{PLACING KNOWLEDGE IN ENGLISH FE TEACHER EDUCATION}

these complexities are reflected in the training curriculum as Young (2013) suggests.

Young (2013) offers 'powerful knowledge' as a means of emphasizing the importance of knowledge as content in the curriculum with its two characteristics: it is specialized in its production and transmission with boundaries between disciplines and subjects, and it is differentiated from everyday experiences that learners acquire in their daily lives. Young and Muller suggest that the science, technology, engineering and mathematics subjects are more obvious examples of 'powerful' knowledge because they 'offer predictions and explanations beyond any that are possible for those who have to rely only on everyday thinking' (2013, p. 245). From the perspective of education as part of the social sciences, this includes some of the science, technology, engineering and mathematics characteristics of 'powerful knowledge' in that it offers generalizations to particular contexts, generates details that are grounded in sufficiently objective methods, and provides evaluative predictions (Young and Muller, 2013).

The derivation of Young's knowledge typology may be traced to the binary division of Bernstein's (2000) vertical and horizontal knowledge and Durkheim's (1993) sacred and profane classification. Bernstein's knowledge classification offers vertical knowledge as knowledge that is explicit, coherent and systematically structured. It has its own acquisition and transmission rules and is mediated by the recontextualization process. Horizontal knowledge is related to the everyday. It is verbal and has context, a tacit nature and locality. Its acquisition is via peer groups and at work. This type of knowledge is not easily translated (Loo, 2006). Vertical knowledge is transmitted to the teacher trainee via the process of recontextualization (Bernstein, 1990). Bernstein views this process as one 'which selectively appropriated, relocates, refocuses, and relates other 
discourses to constitute its own order and orderings' (1990, p. 184). He also indicated the rules surrounding this process: 'The recontextualization rules regulate not only selection, sequence, pace, and relations with other subjects, but also the theory of instruction from which the transmission rules are derived' (1990, p. 185). For Bernstein, the process is a way of the curriculum (i.e. the 'what') and transmission (i.e. the 'how'). In terms of 'sequencing', he offers two varieties: parallel (where two or more aspects of the curriculum such as modules are delivered in parallel) and sequential (where they are delivered in sequence). The selection, sequencing and pacing of the content in a curriculum will be dependent on various contexts such as learners' needs and understanding, amount of content for coverage, and so forth.

Recontextualization as a process is developed further by Barnett (2006), who focused on vocational teaching and learning with two types: re-classificatory recontextualization and pedagogic recontextualization Re-classificatory recontextualization is viewed as a 'toolbox of applicable knowledge', which occupation- related teachers draw from and rely upon. Pedagogic recontextualization is seen as a bridge between 'vocational pedagogy and disciplinary knowledge' (Barnett, 2006, p. 147). van Oers (1998) investigated recontextualization from the perspectives of young people developing abstract thinking in their play activities. He

\section{PLACING KNOWLEDGE IN ENGLISH FE TEACHER EDUCATION 341}

offers two types of recontextualization vertical and horizontal, where the former results from a development of new problems that arise out of a well-known activity such as FE teachers using their occupational experiences in their teaching. Horizontal recontextualization is viewed as an alternative approach to a 'wellknown activity' where the activity is recontextualization (van Oers, 1998, p. 138) such as a teacher using a teaching strategy learned from a colleague (Loo, 2012). Evans et al. (2010) developed the aforementioned forms of recontextualization to provide a deeper understanding of how people learn in different settings such as at work and on a training programme. The four types of recontextualization are: content recontextualization, where the theoretical knowledge is selected in order to make it accessible for learners; pedagogic recontextualization where the theoretical and the everyday knowledge is included in curriculum modules and teaching activities for learning; workplace recontextualization where through mentoring and other support structures, learners learn in work settings; and learner recontextualization where learners use their own strategies to integrate theoretical knowledge and work-related knowledge. These developments of recontextualization processes offer insights into how people learn in different settings may they be on a course, at occupation-related work or as teachers.

Vygotsky offered a slightly different perspective to Durkheim (even though they 
both used a binary typology of knowledge: theoretical and everyday, and sacred and profane respectively) in that he viewed the learning of complex ideas as a twoway pedagogic activity. Learners develop through their learning of new and theoretical concepts, and the acquisition and understanding of the concepts are then used in everyday contexts (Young and Muller, 2013). This modification of 'theoretical' and 'everyday' knowledge offers an explanation of the complex interaction and mutability between knowledge and contexts for people, which differs from Bernstein's and Young's binary distinction of disciplinary and everyday knowledge.

From the perspective of 'teaching' knowledge, the teachers in FE use it in different situations that may be in different teaching institutions such as FE colleges, adult and community settings (e.g. libraries and retirement homes), workplaces and private provider offices. Besides the 'theoretical' and 'the everyday' forms of knowledge as discussed above, others have typologized teaching knowledge into other forms. Shulman (1987, pp. 8-9) focused on knowledge for teacher training with his seven categories of knowledge base: content knowledge (knowledge and skills for learning), curriculum knowledge ('tools of the trade' such as knowledge of materials for use in teaching), general pedagogical knowledge (strategies and rules around classroom management), pedagogical content knowledge (content and teaching are organized, represented and adapted to particular cohort of learners), knowledge of learners and their characteristics, knowledge of educational contexts, and knowledge of educational values.

Loughran et al. explored ways of codifying teachers' professional knowledge in their 12 'Principles of teaching for quality learning', which they suggested enabled teachers to 'identify and articulate important and hitherto hidden aspects of their practice' (2003, p. 856). Some of these principles included: sharing

\section{PLACING KNOWLEDGE IN ENGLISH FE TEACHER EDUCATION}

intellectual control with students, encouraging students to learn from peers' questions and comments, using a variety of intellectually challenging teaching procedures, raising students' awareness of the nature of different components of quality learning and assessing different aspects of quality learning. Verloop et al. (2001) distinguished teacher knowledge into six types, namely: subject matter, students, student learning and comprehension, purposes, curriculum and instructional techniques. These categories were used as a starting basis for analysing the teachers' interactive cognitions and were found to consist of three types - subject matter oriented, student oriented and student learning oriented.

Finally, but by no means least, is Clandinin's (1985) definition of 'personal practical knowledge' that is viewed as connected with personal and professional experiences of teachers' lives, which are emotional and moralistic in characteristics. This knowledge may not be easily articulated or logically defined 
but it has a significant impact on their lives.

The above discussion of the importance of knowledge in teacher education draws mainly on two groups of literature sources: 'the curriculum-related' and the 'typologists'. With the first group, Young, Bernstein and Evans et al. all offer concepts that have direct implications for teacher education curriculum with their 'powerful knowledge' and 'recontextualization' respectively. For Young, knowledge plays an integral part in the content of teacher education in ways that offer generalizations to specific pedagogic contexts, apply research methods to pro- duce new knowledge and create insightful declarations. Bernstein's and Evans et al.'s recontextualization concepts offer approaches to delivering content for learning in varied settings. With the second group (e.g. from Barnett, Clandinin and Shulman), forms of knowledge are viewed as useful concepts to understanding teachers' sources, differentiations and impacts on pedagogic practices. These concepts are therefore not viewed as directly related to curriculum but as typologies to provide further insights into teaching and learning processes.

\section{PROJECT DETAILS}

Data from two projects are used for this article. Project 1 aimed to investigate the types of knowledge that were required in teaching and its application in pedagogic activities (Loo, 2012). Project 2 aimed to identify a structured approach to assist qualified teachers with different pedagogic, life and disciplinary/curriculum backgrounds to enhance their teaching practices through the use of digitally recorded teaching sessions (Loo, 2013).

The data from the projects are directly relevant to this article because they focused on the types of teaching knowledge of newly qualified FE teachers with occupational experience and how such knowledge was used to enhance teaching. Project 1 used questionnaire survey and semi-structured interviews to capture data. Salient details from the survey are included in Table 1. Interviews were carried out on a one-to-one basis, which varied from 45 to 90 minutes. Topic questions were asked, relating to the types of knowledge required in teaching and

\section{PLACING KNOWLEDGE IN ENGLISH FE TEACHER EDUCATION 343}

Table 1. Details of participants

$\begin{array}{lllll}\begin{array}{l}\text { Participant } \\ \text { Gender }\end{array} & \begin{array}{l}\text { Teaching } \\ \text { institutions }\end{array} & \begin{array}{l}\text { Full-time/Part-time } \\ \text { (No of teaching hours }\end{array} & \begin{array}{l}\text { Disciplinary } \\ \text { areas }\end{array} & \begin{array}{l}\text { Occupational/ } \\ \text { life experiences }\end{array} \\ \text { Age } & \text { Level of } & \text { per week) } & & \\ \text { Project } & \text { academic } & \text { Years of teaching } & & \\ \text { participation } & \text { qualifications } & \text { experience } & & \end{array}$




\begin{tabular}{|c|c|c|c|c|}
\hline $\begin{array}{l}\text { A } \\
\text { Female } \\
\text { 40s } \\
\text { P1 }\end{array}$ & $\begin{array}{l}\text { Further } \\
\text { education } \\
\text { college } \\
\text { Level } 5\end{array}$ & $\begin{array}{l}\text { Full-time } \\
4 \text { years }\end{array}$ & $\begin{array}{l}\text { Radio } \\
\text { production } \\
\text { and journalism }\end{array}$ & $\begin{array}{l}\text { Civil servant, } \\
\text { information } \\
\text { researcher and } \\
\text { EFL teacher. } \\
\text { Worked and lived } \\
\text { In Japan. }\end{array}$ \\
\hline $\begin{array}{l}\text { B } \\
\text { Male } \\
50 s \\
\text { P1, } 2\end{array}$ & $\begin{array}{l}\text { Further } \\
\text { education } \\
\text { college } \\
\text { Level } 5\end{array}$ & $\begin{array}{l}\text { Full-time } \\
\text { Over } 3 \text { years }\end{array}$ & $\begin{array}{l}\text { Health and } \\
\text { social care }\end{array}$ & $\begin{array}{l}\text { Worked in the } \\
\text { health and social } \\
\text { care sector. NVQ } \\
\text { assessor. }\end{array}$ \\
\hline $\begin{array}{l}\text { C } \\
\text { Male } \\
40 s \\
\text { P1 }\end{array}$ & $\begin{array}{l}\text { Adult and } \\
\text { community } \\
\text { Level } 5\end{array}$ & $\begin{array}{l}\text { Part-time } \\
(4 \mathrm{hrs} / \mathrm{wk}) \\
6 \text { years }\end{array}$ & $\begin{array}{l}\text { Art - painting } \\
\text { and drawing }\end{array}$ & $\begin{array}{l}\text { Architect and } \\
\text { print maker. }\end{array}$ \\
\hline $\begin{array}{l}\text { D } \\
\text { Female } \\
50 \mathrm{~s} \\
\mathrm{P} 1,2\end{array}$ & $\begin{array}{l}\text { Dental } \\
\text { hygiene } \\
\text { institution } \\
\text { Level } 4\end{array}$ & $\begin{array}{l}\text { Part-time } \\
(10 \mathrm{hrs} / \mathrm{wk}) \\
7 \text { years }\end{array}$ & $\begin{array}{l}\text { Dental hygiene, } \\
\text { psychology and } \\
\text { biology }\end{array}$ & $\begin{array}{l}\text { Dental hygienist. } \\
\text { Lived and } \\
\text { worked abroad } \\
\text { with the Navy } \\
\text { (e.g. Malta). }\end{array}$ \\
\hline $\begin{array}{l}\text { E } \\
\text { Male } \\
50 s \\
\text { P1 }\end{array}$ & $\begin{array}{l}\text { Further } \\
\text { education } \\
\text { college } \\
\text { Level } 5\end{array}$ & $\begin{array}{l}\text { Full-time } \\
4 \text { years ( } 28 \text { years } \\
\text { including other } \\
\text { education sectors) }\end{array}$ & $\begin{array}{l}\text { Mathematics, } \\
\text { physics and } \\
\text { biology }\end{array}$ & $\begin{array}{l}\text { Lived and worked } \\
\text { in South Africa. }\end{array}$ \\
\hline $\begin{array}{l}\text { F } \\
\text { Female } \\
30 \text { s } \\
\text { P2 }\end{array}$ & $\begin{array}{l}\text { Adult and } \\
\text { community } \\
\text { Level } 4\end{array}$ & $\begin{array}{l}\text { Full-time } \\
6 \text { years }\end{array}$ & Life skills and IT & $\begin{array}{l}\text { Lived abroad in } \\
\text { her adolescence } \\
\text { and had } \\
\text { experienced } \\
\text { homelessness and } \\
\text { extreme poverty. }\end{array}$ \\
\hline $\begin{array}{l}\text { G } \\
\text { Female } \\
50 \text { s } \\
\text { P1, } 2\end{array}$ & $\begin{array}{l}\text { Adult and } \\
\text { community } \\
\text { Level } 5\end{array}$ & $\begin{array}{l}\text { Part-time } \\
(4 \text { hrs/wk) } \\
20 \text { years }\end{array}$ & $\begin{array}{l}\text { Art - printmaking, } \\
\text { textiles, drawing } \\
\text { and painting }\end{array}$ & $\begin{array}{l}\text { Worked as a } \\
\text { community } \\
\text { worker at a } \\
\text { women's centre } \\
\text { on art projects } \\
\text { and under fives } \\
\text { project. }\end{array}$ \\
\hline $\begin{array}{l}\mathrm{H} \\
\text { Female } \\
30 \mathrm{~s} \\
\mathrm{P} 1,2\end{array}$ & $\begin{array}{l}\text { Adult and } \\
\text { community } \\
\text { Level } 5\end{array}$ & $\begin{array}{l}\text { Part-time } \\
(5 \mathrm{hrs} / \mathrm{wk}) \\
5 \text { years }\end{array}$ & $\begin{array}{l}\text { Dance and } \\
\text { Feldenkrais } \\
\text { movement }\end{array}$ & $\begin{array}{l}\text { Lived, studied } \\
\text { and worked } \\
\text { abroad. }\end{array}$ \\
\hline $\begin{array}{l}\text { I } \\
\text { Male }\end{array}$ & $\begin{array}{l}\text { Further } \\
\text { education }\end{array}$ & $\begin{array}{l}\text { Full-time } \\
15 \text { years }\end{array}$ & $\begin{array}{l}\text { IT, art and } \\
\text { palmistry }\end{array}$ & $\begin{array}{l}\text { Graphic artist, } \\
\text { homeopath, }\end{array}$ \\
\hline
\end{tabular}


50s college

palmist and

P1, $2 \quad$ Level 5

reflexologist.

Worked and

lived in

Australia,

Switzerland

and the US.

\section{PLACING KNOWLEDGE IN ENGLISH FE TEACHER EDUCATION 345}

their application with reference to their teaching training and post-qualification pedagogic experiences. Project 2 used digital recordings of the six participants each teaching to the same student cohorts over three different sessions (totalling 18 recordings). Each participant then chose one recording for analysis in a peer review process. These focus group interviews also were recorded on audiocassette. The researcher transcribed the data, like in the interviews in the other project. A questionnaire survey was completed electronically and the salient details are also included in Table 1.

In both projects, the participants were former trainee teachers on the Postgraduate Certificate of Education (Post-compulsory/FE) programme. The project researcher was a tutor on the programme. There were eight volunteers in the first project and six volunteers in the second, with five taking part in both projects. Table 1 presents details of the nine participants.

The group of nine volunteers included five females and four males; two were aged in the 30s, two were aged in their 40s and five were aged in their 50s. Four participants taught in FE colleges, four in adult and community settings and one participant in a HEI. The length of their teaching experience varied from over three to 28 years and five participants were in full-time employment and four in part-time. The disciplinary/curriculum taught by the teachers included: art, biology, dance, dental hygiene, health and social care, information technology, journalism, life skills, mathematics, palmistry, physics, psychology and radio production. Some of the teachers taught in more than one subject area and the levels at which these were delivered: life skills, dance, palmistry and art-related areas were at Level 1 (which were non-accredited), and the rest except for one were up to Level 3 (equivalent to 'Advanced' or pre-university level). The exception was the area of dental hygiene, which was at undergraduate level. In terms of occupational and life experiences, six participants had worked and/or lived abroad in countries such as Australia, Japan, Malta, South Africa, Switzerland, and the United States. All of the participants had attained Level 5 qualifications (doctorate, master's or postgraduate diploma) except for two participants with Level 4 qualifications (first degree). These professional and 
biographical details are significant and relevant as they provide specific contexts to individual cases in the discussion of this article.

\section{DISCUSSION}

In this section, the article argues for the significance and inclusion of knowledge in teacher training, which is research based, and for a collaborative and not a competitive approach in teacher education where related stakeholders such as teachers, researchers and policy-makers are encouraged to support and take part in evidence-informed research towards the continuous development of teaching knowledge.

The Further Education National Training Organisation standards for teaching and supporting learning in FE provided a 41-page document to 'inform the

\section{PLACING KNOWLEDGE IN ENGLISH FE TEACHER EDUCATION}

design of accredited awards for FE teachers' and not to 'prescribe the detailed nature of qualifications for teachers' $(1999, \mathrm{p} .1)$. The document offered four sets of values relating to reflective practice and scholarship, collegiality and collaboration, centrality of learning and learner autonomy, and entitlement, equality and inclusiveness. This set of standards for all teacher training courses, which were accredited by awarding bodies and HEIs, had three elements: professional knowledge and understanding, skills and attributes, and key areas of teaching. Three types of knowledge were identified: domain-wide knowledge, which applied to all areas of teaching such as adult literacy, vocational and academic subjects; generic knowledge, which related to each standard; and essential knowledge, which related to specific aspects of each standard. A list of the teachers' skills, such as research and study, collaborative working and networking, and attributes, such as appreciation of FE values and ethics, was given. The eight keys areas of teaching included: assessing learners' needs, planning and preparing programmes, developing and using a range of teaching and learning techniques, managing the learning process, providing learners with support, assessing outcomes, critiquing personal performance, and meeting professional requirements. Under each of the eight areas was further listing of teaching and learning outcomes under the generic and essential knowledge headings. The document is a prescriptive competence-based listing of items from pages five to 41 .

Perhaps the overly prescriptive approach was taken in order to cover the varied forms (in terms of subject areas and levels) of teaching training programmes. However, it does offer platforms for a collaborative approach and carrying out research and professional development in relation to trainee teachers as explicated in its four sets of values. Similarly, there are attempts to introduce the idea of 
knowledge into the professional training of teachers, which is a positive, but the sources and descriptions of knowledge from research-based literature were not indicated.

Turning to the current guidance document (LSIS, 2013b), this consists of 38 pages comprising four sections: an overview, a description of the qualifications, explanation of the implications of the changes to the qualifications, and indicative examples of an effective teaching training programme. The major change in this document relates to the introduction of varied levels and pathways of teaching qualifications. In terms of levels, there are three: Level 3, Level 4 and Level 5 qualifications for generic qualifications. In terms of pathways, in addition to generic ones, there are integrated specialist diplomas and stand-alone specialist diplomas all at Level 5. For the purposes of this article, the teaching qualifications at Level 5 will be considered since they covered all the three types of diplomas. These have 120 ( 75 mandatory and 45 optional) credits with the one exception of the combined specialist pathway of English (Literacy and ESOL), which is worth 135 credits. These credits relate to "the study of underpinning theories, frameworks and research into effective teaching and learning alongside the development of practical teaching skills' (LSIS, 2013b, p. 18) and involve

\section{PLACING KNOWLEDGE IN ENGLISH FE TEACHER EDUCATION 347}

knowledge and application of theory and pedagogical principles, and use of technologies (LSIS, 2013b). Also included are 100 hours of teaching practice, 50 hours of which should be in the chosen specialist area. In addition, an effective teacher training course, according to the current set of specifications, focuses on the trainee teacher's ability to link theory, such as subject and pedagogic knowledge, to practice. It encourages trainees to learn from other practitioners, and recognizes the trainee teacher's previous experience and existing skills. There is a shift from a prescriptive and competence-driven list of learning outcomes to a more pathway-based series of training programmes at three levels. There are, however, commonalities between the two sets of qualifications with regard to collaboration, brief references to research and professional development and an effort to inject knowledge into the training of teachers.

It is with this background in mind that this section offers a collaborative and reflective peer review approach to enhancing trainee teachers' pedagogic activities with the integration of subject and pedagogic knowledge. Using the findings from Project 2, Teacher B, a male qualified teacher in his 50s working in a FE college and specializing in health and social care with occupational experience, remarked on the digital recording of the participant's (Teacher D) dental hygiene session entitled 'Taking History':

I think viewing the [digital recording] with those involved demonstrated that an observer 
may not be aware of the bigger picture. Learners in a classroom etc. are not blank canvases. There may be other factors going on: in the learners' lives; learning environment affecting them; the group dynamics; and the teacher-prospective rapport. An observer either attending in person or watching a recording would not necessarily be aware of these factors. (Teacher B)

The 'situated learning' (Lave and Wenger, 1991) contexts of this particular teaching session are relevant to peers understanding the 'Taking History' recording as mentioned by Teacher $\mathrm{B}$. Teacher $\mathrm{D}$ indicated to her peers that two of her students were examined in a viva whilst the recorded session was going on and they were aware of the significance of the viva activity on their two colleagues since the outcome would affect their overall examination results. Perhaps this context might explain the students' more than usual inattentiveness. This behaviour was remarked upon by one of the teachers in the peer review (of the recording). Similarly, Teacher D positioned herself in such a way that she would be able to see the imminent possibility of the viva students entering the teaching session. Learners were conscious of their colleagues' viva activities and exhibited an apparent empathy for their colleagues' situation. This affected the group dynamics, such as the inattentiveness of the students, and to a degree also Teacher D's positioning in the session. Although it was apparent from the recorded session that the learners were not attentive as remarked by another teacher, the relevant contexts of this specific learning session were not known.

\section{PLACING KNOWLEDGE IN ENGLISH FE TEACHER EDUCATION}

The complexity of teaching and learning was captured in this pedagogic research. Scholars used the categorization of pedagogic knowledge to investigate the sources, forms and their relevance to teaching. Young's (2013) 'powerful knowledge' relates the teaching of the disciplinary knowledge of dental hygiene (as part of the science, technology, engineering and mathematics disciplines) in this teaching example. Teacher D also taught biology and psychology to the class of dental hygienists and, drawing on Young, the two disciplinary forms of knowledge (biology and psychology) would be delivered in a different subject area (dental hygiene). Although the disciplinary knowledge might be argued as 'theoretical knowledge' because it was differentiated from everyday experiences. However, one could suggest that the application of disciplinary knowledge in a different subject area must modify the nature of the knowledge from the perspectives of Teacher D and also for her learners as the disciplinary knowledge was recontextualized in another subject area. This example of ongoing recontextualization must modify the theoretical knowledge as it interacted with different applications in another subject. Thus the notion of recontextualization is nearer to Vygotsky's (1962) theory involving the learning of complex ideas as a two-way pedagogic activity, where learners acquire new theoretical concepts and apply in other contexts. Furthermore, Shulman's (1987) and Verloop et al.'s 
(2001) knowledge of learners appear to be similar, although in this specific example there was a significant degree of the students' tacit knowledge of and empathy for their viva colleagues' situation.

Teacher $\mathrm{H}$ taught dance in adult and community settings on a part-time basis, having completed a degree in dance and for a while lived and worked abroad with a modern dance group. In the comment below, she remarks on the advantage of recorded teaching sessions where specialist and pedagogical tutors could be called upon to discuss the disciplinary and teaching knowledge in relation to that specific 'Taking History' session:

There was a value in a non-specialist observation as the observer could go in with an objective mind because he/she was not a specialist, then he/she would look at pedagogy (and not subject knowledge). There was value in itself. This would be 360 degree evaluation. (Teacher $\mathrm{H})$

The teachers who took part in Project 2, from which the above quotation was taken, saw the peer review of the recorded teaching sessions as crucial to the better understanding of teaching activities and a crucial platform to integrating disciplinary and pedagogic knowledge from a teaching practice perspective. The use of recorded teaching sessions with a structured approach has the advantage of offering the peer group members another perception of reality (Loo, 2013) to discuss in additional space and time (away from their teaching settings and time) collaboratively between peers in a constructive manner in order to enhance each other's teaching. Peers may act as a 'fresh pair of eyes' to bring out issues that may not be apparent to the recording teacher alongside a space for reflection, a framework was established to analyse recorded teaching sessions and a

\section{PLACING KNOWLEDGE IN ENGLISH FE TEACHER EDUCATION 349}

preference for collaborative activity was identified (Loo, 2013). These points chime with Coffield's (2014) 'JPD' concept, which refers to teachers jointly (J) sharing their practice (P) in order to develop (D) their teaching activities. This collaborative approach of using recorded digital teaching sessions in a reflective peer review approach has the hallmarks of Coffield's 'JPD' concept.

From the perspectives of locating knowledge in teacher education, Bernstein's (1990) and Evans et al.'s (2010) recontextualization concepts are helpful in understanding pedagogic knowledge, as these relate to how the vertical knowledge - that is, the content of the teacher education curriculum - is selected, relocated, refocused and related to other discourses to form its own order and orderings (Bernstein, 1990). To a large extent, Evans et al.'s forms of recontextualization (i.e. content and pedagogic) are derived from Bernstein. Shulman's (1987) general pedagogical content knowledge, such as the organization, representation and 
adaptation to particular learners, has similar resonances to Bernstein's. Like the discussion of disciplinary knowledge in the previous quotation, other types of pedagogic knowledge are also important in facilitating trainee teachers' understanding of how these types of knowledge may be applied in their teaching activities.

The next two teachers - Teachers $\mathrm{G}$ and $\mathrm{D}$ - remarked on the tacit nature of teaching. Teacher $\mathrm{G}$ was a practicing artist in printmaking, textile designing, drawing and painting as well as a part-time teacher of art in adult and community settings. She came from an artistic family where her father was a full-time artist. Teacher D worked as a part-time teacher in dental hygiene and practiced as a dental hygienist. Her 'Taking History' session was discussed earlier:

There is so much about the subtlety of teaching which you can't write about in great detail but much easier to look at it, like a [digitally recorded] session, and to discuss it. (Teacher G)

It is difficult to teach manual dexterity as you need to be like a detective by being able to look into somebody's mouth, describe what you see and be able to say why it is different and work out provided they (the learners) have the theoretical knowledge and that they are able to apply it to the situation. There are transitional stages where the students can apply their theoretical knowledge, each of them to detect and identify deposits on the teeth and how to remove it and having the confidence to remove them. Students are afraid to harm the patient, which it should be but experienced tutors know the amount of pressure to use and perhaps the angle of applying the instrument. That itself is quite hard to impart. (Teacher D)

The peer review teachers focused on the artistry and tacit nature of teaching in the above two comments. Young's (2013) 'powerful knowledge' is not featured in this discussion as it is not disciplinary knowledge but pedagogic-related knowledge and/or tacit (referring to his derivation of Bernstein's knowledge classification and, in this case, horizontal knowledge). The above forms of knowledge espoused by Teachers $G$ and D may neither fit neatly with Bernstein's vertical and horizontal forms as they include disciplinary and

\section{PLACING KNOWLEDGE IN ENGLISH FE TEACHER EDUCATION}

pedagogic knowledge, and teaching and occupational experiences. Although these sources and forms of knowledge are nearer to the truth in reality, from a Bernsteinian point of view they are not. Shulman's (1987) seven categories of knowledge base also offer little by way of the tacit aspects of knowledge. Loughran et al.'s (2003) 'hidden aspects of teaching practice' are also relevant, but these aspects relate to encouraging trainee teachers to learn from peers, raising students' awareness of learning and sharing of intellectual control with students. The three aspects have some resonance with the tacit nature of teaching and 
learning and the complexity and subtlety of teaching. Verloop et al.'s (2001) categories relate more to the teacher's interactive cognitions relating to subject matter, students and their learning rather than the tacit aspects gained from occupational experiences.

The final three quotes below illustrate the complex symbiotic relationships between teaching and occupational practices by Teachers C, D and I. Teacher C taught in adult and community settings as a part-time lecturer in art, where he used a combination of his occupational experiences of architecture (qualified and practiced as one) and art (practiced as a printmaker) in his teaching. Teacher $\mathrm{D}$, as already mentioned, worked as a dental hygienist and lectured in that subject. Teacher I worked as a full-time lecturer in an FE college. His areas of specialism included information technology, art and palmistry as well as being a practitioner in graphics, homeopathy, palmistry and reflexology. He had lived and worked in Australia, Switzerland and the United States before settling in England:

Teaching motivates me, gives me a sense of purpose and making a difference as well as informs my occupational practices e.g. creation of an ideal home as a theme with students, parents and teachers as a way of managing art, architecture and teaching. (Teacher C)

The transition from practice (as a dental hygienist) to teaching is easier if I practice regularly to keep my confidence level and speed up. (Teacher D)

I've been a student and lecturer for the past ten years so my experiences have been on both sides of the fence and in homeopathy as a student and seeing how different teachers cope ... invariably, my experiences as a teacher and as a student always apply in my teaching, as I am a perpetual student. My approach to teaching is not to use a big stick and not dumb down to primary and secondary levels but work on delivery and start from learners' world. I believe that my extensive life and work experience gained from living and working in Australia, Switzerland and the US as well as here in the UK has given me a tolerant and curiosity-focused approach to the education process. (Teacher I)

These quotes offer evidence of teachers' perceptions as regards the mutability of disciplinary/theoretical knowledge and the everyday of life, occupational and teaching experiences. These teachers relate these knowledge forms as a complex ongoing recontextualization process, which integrates the theoretical and horizontal knowledge (Loo, 2012) unlike the immutability of the concepts by Bernstein (1990) and Young (2013). The first and second quotes identify the

\section{PLACING KNOWLEDGE IN ENGLISH FE TEACHER EDUCATION 351}

relationships between occupational and pedagogic practices where one may inform the other and vice versa, and the third quote draws on occupational, pedagogic and life experiences. Clandinin's (1985) 'personal practical 
knowledge', which relates personal and professional experiences of teachers' lives in the compulsory education sectors, are relevant in these qualitative data where teachers' emotional and moralistic perspectives are featured especially with Teacher I's empathy with his learners and a particular pedagogic stance towards his learners.

These qualitative data also show the inter-relationships between knowledge from life, occupational and pedagogic experiences whether they are explicit or tacit in nature, theoretical or the everyday types. The typologies of knowledge by Young, Bernstein, Vygotsky, Shulman, Loughran et al, and Verloop et al. serve as possible platforms to understanding teaching knowledge, not as an end in themselves but as windows of discussions to engaging with knowledge and its application to the complexities of teaching.

\section{WHERE TO NEXT?}

This article offers a curriculum solution to the current under-developed and inconsistent approach to integrating disciplinary and pedagogic knowledge in FE teacher education in England. This pedagogic solution draws on data from two projects and uses Young's advocacy of locating knowledge in the curriculum by using a collaborative and research-driven approach with relevant stakeholders and the engagement of teachers. This research-driven approach is a starting point for future development. Collaborative research with other stakeholders such as researchers and policy-makers has the potential to add to the under-developed body of research in FE that Coffield lamented in the late 1990s. Research studies by Hefferman (2014) and Sawyer (2007) offer hope of moving from the politically driven and unproven ideology of market competition to a collaborative variety so that stakeholders can engage fruitfully with each other with a common purpose of producing and supporting quality teaching. There are already research-related networks in place in the sector such as those the British Educational Research Association, the Further Education Research Association, the Learning and Skills Research Network and the Teacher Education in the Lifelong Learning Sector contribute to. In order for teachers to engage actively in research, relevant stakeholders such as FE colleges and HEIs and national agencies such as the Education and Training Foundation should offer support in facilitating FE teachers and related researchers to use their 'civic courage' and 'intellectual labour' to become 'producers' of knowledge (Welker, 1992) in the FE sector and not merely consumers of knowledge produced by others. The recent British Educational Research Association - Royal Society for the Encouragement of the Arts, Manufacturing and Commerce (2014) report offers four forms of research-related aims: the content of teacher education programmes may be informed by researchbased knowledge; research should inform the

352 PLACING KNOWLEDGE IN ENGLISH FE TEACHER EDUCATION 
design and structure of such programmes; teachers should be encouraged to be discerning consumers of research; and teachers and teacher educators should be equipped to carry out research.

This article has highlighted three of these approaches and has argued the importance of professional knowledge in the FE teacher education curriculum. The research suggest that a curriculum approach using technology (BIS, 2014) to record teaching sessions facilitates the development of trainee teachers' understanding of teaching. It also highlights the value of a collaborative and researchdriven approach in the FE teacher training programme. The research drew on two forms of ongoing recontextualization - disciplinary knowledge between subject areas and between disciplinary/theoretical knowledge and everyday (tacit) experiences - and included two of the themes from the teaching qualifications (Further Education National Training Organisation, 1999; LSIS, 2013a, 2013b).

The implications of this work for the teachers are a '360 degree' training experience where they can link disciplinary and pedagogic knowledge in their teaching activities and work collaboratively to improve teaching quality. For teaching institutions, with an expansive (and supportive) structure, a more professional workforce where research-driven activities inform professional development can create 'producers' and not mere consumers of pedagogic knowledge. The enhancement of the workforce and teaching quality would hopefully feed into the achievements of learners and inspection outcomes. From the perspectives of policy-makers, the emphasis on knowledge content in the teacher education programmes and on the support given to research activities would professionalize and upskill the teaching workforce with the eventual hope of increasing the ability of the workforce (formerly students) to compete on a global stage.

\section{ACKNOWLEDGEMENTS}

The author would like to thank Jim Crawley, Norman Crowther and Dan Taubman for their useful comments and the reviewer(s) for the supportive and helpful suggestions.

\section{REFERENCES}

Barnett, M. (2006) Vocational knowledge and vocational pedagogy. In M. Young and J. Gamble (Eds) Knowledge, Curriculum and Qualifications for South African Further Education (Cape Town, Human Sciences Research Council Press), 143-158.

Bernstein, B. (1990) The Structuring of Pedagogic Discourse: Class, Codes and Control (London, Routledge).

Bernstein, B. (2000) Pedagogy, Symbolic Control, and Identity (New York, Rowman and 
Littlefield).

British Educational Research Association - Royal Society for the Encouragement of the Arts, Manufacturing and Commerce (2014) Research and the Teaching Profession:

\section{PLACING KNOWLEDGE IN ENGLISH FE TEACHER EDUCATION 353}

Building the Capacity for a Self-improving Education System. Final Report of the

BERA-RSA Inquiry into the Role of Research in Teacher Education (London, BERA). Clandinin, J. (1985) Personal practical knowledge: a study of teachers' classroom images,

Curriculum Inquiry, 15 (4), 361-385. Coffield, F. (1998) A fresh approach to learning for the learning age: the contribution of research, Higher Education Digest, 31, 4-

6. Coffield, F. (2014) Beyond Bulimic Learning: Improving Teaching in FE (London,

Institute of Education Press). Department for Business, Innovation and Skills (2012a) The Richard Review of Apprenticeships (London, BIS). Department for Business, Innovation and Skills (2012b) Professionalism in Further

Education: Final Report of the Independent Review Panel (London, BIS). Department for Business, Innovation and Skills (2014) Further Education Workforce Strategy: The Government's Strategy to Support Workforce Excellence in Further

Education Colleges and Training Providers (London, BIS). Department for Education (2010) The Importance of Teaching (Cm 7980) (London, The

Stationery Office). Department for Education (2011) Review of Vocational Education The Wolf Report

(London, DFE). Durkheim, E. (1993) The Division of Labor in Society (New York, Macmillan). Education and Training Foundation (2014) Professional Standards for Teachers and

Trainers in England: Initial Guidance for Users (London, ETF). Evans, K., Guile, D., Harris, J. and Allan, H. (2010) Putting knowledge to work: a new approach, Nurse Education Today, 30 (3), 245-251. Further Education National Training Organisation (1999). Standards for Teaching and

Supporting Learning in Further Education in England and Wales (London, FENTO). Hefferman, M. (2014) A Bigger Prize: Why Competition Isn't Everything and How We Do

Better (New York, Simon and Schuster). Lave, J. and Wenger. E. (1991) Situated Learning: Legitimate Peripheral Participation (Cambridge, Cambridge University Press).

Learning and Skills Improvement Service (2013a) Teaching and Training Qualifications 
for the Further Education and Skills Sector in England (2013): Guidance for employers and practitioners (Coventry, LSIS).

Learning and Skills Improvement Service (2013b) Teaching and Training Qualifications or the Further Education and Skills Sector in England (2013): Guidance for initial teacher education providers (Coventry, LSIS).

Learning and Skills Improvement Service (2013c) Commission on Adult Vocational Teaching and Learning (Coventry, LSIS).

Loo, S. (2006) Adult numeracy teacher training programmes in England: a suggested typology, International Journal of Lifelong Education, 25 (5), 463-476.

Loo, S. Y. (2012) The application of pedagogic knowledge to teaching: a conceptual framework, International Journal of Lifelong Education, 31 (6), 705-723.

Loo, S. Y. (2013) Professional development of teachers: using multimodality and reflec- tive peer review approaches to analyse digitally recorded teaching practices, Teacher Development: An International Journal of Teachers' Professional Development, 17(4), 499-517.

Loughran, J., Mitchell, I. and Mitchell, J. (2003) Attempting to document teachers' professional knowledge, Qualitative Studies in Education, 16 (6), 853-873.

Pye Tait Consulting (2014) Professional Standards for Teachers and Trainers in England (London, The Education and Training Foundation).

Sawyer, K. (2007) Group Genius: The Creative Power of Collaboration (New York, Basic Books).

\section{PLACING KNOWLEDGE IN ENGLISH FE TEACHER EDUCATION}

Shulman, L. S. (1987) Knowledge and teaching: foundations of the new reform, Harvard Educational Review, 57 (1), 1-22.

Tatto, M. T. (2013) Changing trends in teacher education policy and practice: international perspectives and future challenges for educational research, Research Intelligence, 121, 16-17.

van Oers, B. (1998) The fallacy of decontextualisation, Mind, Culture and Activity, 5 (2), $143-152$.

Verloop, N., Van Driel. J. and Meijer. P. (2001) Teacher knowledge and the knowledge base of teaching, International Journal of Educational Research, 35 (5), 441-461.

Vygotsky, L. S. (1962) Thought and Language (Cambridge, MA, Massachusetts Institute of Technology Press). 
Welker, R. (1992) The Teacher as Expert: A Theoretical and Historical Examination (Albany, NY, State University of New York Press).

Young, M. (2013) Overcoming the crisis in curriculum theory: a knowledge-based approach, Journal of Curriculum Studies, 45 (2), 101-118.

Young, M. and Muller, J. (2013) On the powers of powerful knowledge, Review of Education, 1 (3), 229-250.

Correspondence

Sai Y. Loo Institute of Education, University of London, 20 Bedford Way, London WC1H 0AL, UK Email: s.loo@ioe.ac.uk 